\title{
The State of Democracy in the Andes: \\ INTRODUCTION TO A THEMATIC ISSUE OF \\ Revista de Ciencia Política
}

\section{El estado de la democracia en los Andes: Introducción a un número temático de la Revista de Ciencia Política}

\author{
MAXWELL A. CAMERON* \\ University of British Columbia
}

\begin{abstract}
This overview finds evidence for concern about the ability of the governments in Colombia and Venezuela to hold free and fair elections and a trend toward the concentration of executive power in most countries in the sub-region. The separation of powers has been most sharply eroded in Venezuela; but Bolivia and Ecuador are moving in a similar direction. Colombia has a robust constitutional order, including a remarkably independent judiciary which has resisted the concentration of executive power by refusing to let the president stand for a third term. At the same time, most Andean countries are experimenting with new mechanisms of participation. There are sharp contrasts between the model of participation in Bolivia and Venezuela, two countries often lumped together by observers; and, despite ideological differences, striking similarities in the presidential styles of Presidents Uribe and Chávez. Among Andean nations, only Chile is not undergoing a revolution in participation. Finally, Venezuela, Bolivia, and Ecuador have re-written their constitutions in an attempt to encourage the exercise of constituent power. These cases exhibit variation in terms of the degree to which deliberative, pluralistic, lawful, and constitutional procedures were used.
\end{abstract}

Key words: Democracy, elections, constitutions, citizenship, participation, separation of powers, presidentialism.

\begin{abstract}
RESUMEN
Esta sintesis concluye con preocupación respecto a la habilidad de los gobiernos de Colombia y Venezuela para celebrar elecciones libres y justas. También se reporta una tendencia presente en la mayoría de los países de la subregión, en cuanto a la concentración de poder en la rama ejecutiva del gobierno. La separación de poderes se encuentra profundamente comprometida en Venezuela, al tiempo que tanto en Bolivia como en Ecuador se vislumbran movimientos en la misma dirección. Colombia tiene un orden constitucional robusto, incluyendo la meritoria presencia de un
\end{abstract}

* Generous funding for the Andean Democracy Research Network was provided by the Glyn Berry Program in the Global Peace and Security Fund of the Department of Foreign Affairs and International Trade, Canada. I am grateful to all the participants of this network for their input, including Luis Gomez Calcaño, Thais Maingon, Carlos Aponte, Magally Huggins, Michael Penfold, Felipe Botero, Helena Alviar García, Gary W. Hoskin, Mónica Pachón, Rafael Roncagliolo, Carlos Toranzo, Gonzalo Rojas, Eduardo Rodriguez Veltzé, Moira Zuazo, Miguel Ruiz, Simón Pachano, Santiago Basabe-Serrano, Andrea Sanhueza, Manuel Antonio Garretón, and David Altman. I am also grateful to colleagues Juan Pablo Luna, Jennifer McCoy, Eric Hershberg, Allan Tupper, Ken Carty, and Mark Warren for advice, for research assistance by Jason Tockman, Jan Boesten, and Agustín Goenaga, and project management by Rebecca Monnerat. The author alone is responsible for errors of fact or interpretation. 
Poder Judicial independiente capaz de frenar la creciente concentración de poder en el Ejecutivo con su rechazo a la posibilidad de una tercera elección presidencial. Sin embargo, la creciente concentración de poder en el Ejecutivo compromete el orden constitucional. Al mismo tiempo, la mayoría de los países andinos están experimentando con nuevos mecanismos de participación ciudadana. En este sentido, se verifica un amplio contraste entre dos casos usualmente vistos como similares en la literatura (Bolivia y Venezuela), junto con tendencias convergentes, entre casos cuyos liderazgos presidenciales (Alvaro Uribe y Hugo Chávez) poseen orientaciones ideológicas muy diferentes (Venezuela y Colombia). Entre los países andinos, sólo Chile no se encuentra viviendo una revolución participativa. Finalmente, Venezuela, Bolivia y Ecuador han reformado sus constituciones, en un intento por promover el poder constituyente. Estos tres casos exhiben diferencias en términos de la legalidad, el pluralismo, y el tipo de proceso deliberativo que condujo a la reforma constitucional.

Palabras clave: Democracia, elecciones, constituciones, ciudadanía, participación, separación de poderes, presidencialismo.

\section{INTRODUCTION}

The articles in this special issue form part of a project to assess the state of democracy in the Andean region undertaken by the Andean Democracy Research Network. We began with a simple premise: that democracy can be analyzed and evaluated at three distinct levels. First, it is widely accepted that elections are an essential feature of democracy. We therefore place electoral democracy, or polyarchy, at the centre of our analysis. ${ }^{1}$ Yet we also recognize that polyarchy omits (quite deliberately) a set of constitutional features of modern political systems that turn out to be problematic in many newer democracies: the independence of the judiciary, the degree of civilian control over the armed forces, the extent to which the executive abides by the rule of law, and the productivity of the legislature. Finally, we also recognize that democracy is not meaningful unless it offers the citizens mechanisms by which to influence the decisions that directly affect their lives. In other words, democracy is about more than voting and rights, it is also about citizenship and participation. In line with this thinking, we developed a Decalogue. We asked researchers in six countries to analyze the state of democracy according to the following criteria: ${ }^{2}$

\section{Electoral Democracy:}

(1) The right to vote is respected

(2) Elections are clean

(3) Elections are free

\footnotetext{
Dahl (1971) and Przeworski (1991).

The findings reported in this overview article encompass both the reports published in this thematic issue of the Revista de Ciencia Politica, as well as those that will appear in separate publications. They include Gomez Calcaño, Luis, et al. "Venezuela: Democracia en crisis"; Bejarano, Ana María \& Helena Alviar, "Colombia: La dimensión constitucional de la democracia"; David Altman and Juan Pablo Luna, "Chile ¿Institucionalizacion con pies de barro?; Toranzo Roca, Carlos, Eduardo Rodríguez Veltzé \& Carlos Romero, “Bolivia: Diagnóstico de la democracia boliviana"; Roncagliolo, Rafael et al., "Perú: Ejercicio de la representación y la participación política"; Miguel Arnulfo Ruiz Acosta, "Democracia, proceso constituyente y nueva Constitución en el Ecuador contemporáneo". A number of these publications will appear in a forthcoming book to be published by the Instituto de Estudios Peruanos (IEP). Another report, by Gonzalo Rojas Ortuste, entitled "Bolivia ante el cambio: ¿Reforma pactada o revolucionarismo etnicista?" will be published with Umbrales in Bolivia.
} 
(4) Public officials are elected and allowed to govern ${ }^{3}$

\section{Constitutional Democracy: ${ }^{4}$}

(5) Executive and legislative branches of government are independent

(6) The judiciary is independent from the executive and legislature ${ }^{5}$

(7) Civilians have supremacy over the armed forces, exceptional powers are not abused, and the media is free

Citizens' Democracy:

(8) Rights of citizenship -civil, political, social and economic- are protected

(9) Active participation is encouraged through diverse mechanisms

(10) Where constitutions are rewritten, this is done by deliberative, pluralistic, lawful, and constitutional procedures ${ }^{6}$

To begin with electoral democracy, the first observation concerns elections in Venezuela and Colombia: although both Presidents Alvaro Uribe and Hugo Chávez enjoy broad popularity, there are serious problems with electoral processes, actors, and institutions in the two countries. For sharply contrasting reasons, there is a solid basis for concern about the ability of the governments in both countries to hold elections in the future that will meet basic normative standards. The second observation concerns the constitutional separation of powers. There is a trend toward the concentration of executive power in most countries in the sub-region. The separation of powers has been most sharply eroded in Venezuela. Bolivia and Ecuador are moving in a similar direction. Although Bolivia has avoided the destruction of its congress, both countries have lost judicial independence. The case of Colombia represents an interesting novelty. Colombia has a robust constitutional order, including a remarkably independent judiciary. Here too, however, constitutional order is threatened by the growing concentration of executive power. Notwithstanding this threat, the decision by the courts to deny Uribe the chance to run for a third term in office is a major victory for the constitutional separation of powers. Peru is in a period of constitutional re-equilibration, while the separation of powers is fully functional in Chile.

The third finding is that Andean countries are experimenting with new mechanisms of participation. Without hyperbole, the sub-region is moving from a crisis of representation to a revolution in participation. Depending on the model of participation adopted, this may result in important tensions between participation and representation. Within

3 These criteria are drawn from the United Nations Development Program (2004), pp. 77-84.

4 These are issues that fall broadly under the rubric of what Guillermo O'Donnell (2007: 49-75) calls "horizontal accountability".

5 Although Gerry Munck (in this volume) rightly notes that independent judiciaries may serve as countermajoritarian institutions, most of the day-to-day, routine work of courts involves the interpretation and application of existing laws, which, insofar as they are produced by representative legislatures, are expressions of the will of the majority. An independent judiciary is, therefore, both an essential guarantee as well as a potential constraint on the will of the majority.

6 Initially, the last three encompassed respect for civil, political, and social and economic rights, respectively. In the course of the research it became clear that we also needed to address mechanisms of participation and constitutional reform. 
this general point, there are a number of subsidiary observations worth mention: (1) There are sharp contrasts between the model of participation in Bolivia and Venezuela, two countries often lumped together by observers. (2) Despite ideological differences, there are striking similarities in the presidential styles of Uribe and Chávez. (3) Among Andean nations, only Chile is not undergoing a revolution in participation. Peru has adopted legislation to facilitate participation but has done less than other countries in the region to promote participation in practice.

Finally, three of our six cases -Venezuela, Bolivia, and Ecuador- have re-written their constitutions in an attempt to encourage the exercise of constituent power. These cases exhibit variation in terms of the degree to which deliberative, pluralistic, lawful, and constitutional procedures were used. Whereas Venezuela's Chávez used constitutional reforms to neutralize and control existing institutions, Evo Morales exhibited a greater willingness to work within Bolivia's democratic institutions and negotiate with his adversaries. Although Correa, like Chávez, approached constitutional reform in a highly confrontational and partisan manner, the constituent assembly process in Ecuador was broadly inclusive of civil society.

\section{ELECTORAL DEMOCRACY: CORE INSTITUTIONS AT RISK IN COLOMBIA AND VENEZUELA}

All Andean governments enjoy democratic legitimacy in the sense that periodic elections are held that express the will of the majority, and nowhere are irregularities so widespread or systematic as to cast doubt on whether governmental incumbents rightfully hold office. In most cases, the right to vote is respected, elections are clean and free, and public officials are chosen by means of elections and allowed to govern. Nevertheless, the articles in this thematic issue by Michael Penfold and Felipe Botero and his colleagues suggest that in two countries, Colombia and Venezuela, problems have been identified that raise significant questions about the electoral process. These problems are alarming insofar as they affect the core institutions of electoral democracy.

The government of Venezuela has violated a fundamental political right: the right to run for public office. The Comptroller General impeded candidates from running for public office without due process of law (see Penfold). Over 2/3rds of the persons on a list of banned candidates, named the Russián list (after Clodosbaldo Russián, the Comptroller General) were from the opposition, including a number of prominent leaders. The denial of the right to run for office without a trial constitutes not only a violation of a basic political right but also of the presumption of innocence. Moreover, the acceptance of such prohibitions by the National Election Council (CNE), the Human Rights Ombudsperson, and the Supreme Tribunal of Justice sets a dangerous precedent for the exercise of administrative prerogative over the guarantee of a basic political right. In short, the Russián list points to a deeper problem: the politicization of state institutions.

In Colombia, the problems of electoral democracy are of a different nature. The government agency responsible for organizing elections, the National Election Council 
(CNE), is widely regarded as an efficient and clean operation: votes are collected and counted honestly. The election system itself works; the problem is political actors, not public institutions. Violence by illegal actors (paramilitary organizations, guerrillas, drug dealers) affects both the ability to vote and to run for office. The threat or use of coercion can intimidate candidates, deterring them from running for office and discouraging voters from voting. Many candidates have been killed, including prominent national leaders. Guerrilla violence in the past tended to be more indiscriminate (aimed at disruption of elections) and paramilitary violence more targeted (aimed at influencing the outcome). More recently, the FARC has also sought to win municipalities with the objective of capturing and siphoning off revenue. Violence is most intense in rural areas where a large number of voters report being pressured or threatened either to vote for a particular candidate or not to vote at all. Many voters flee the countryside, losing their land in the process.

Until the parapolitica scandal, most observers thought that Colombian elections were clean. It now appears they are not. The parapolitica scandal refers to agreements between paramilitary leaders and local politicians. Voters themselves perceive this as a limitation on the freedom and fairness of elections. The parapolitica scandal is significant for three reasons. First, coercion limits pluralism. Candidates can be intimidated into not running so that the paras get their own candidate in office. Second, the influence of the paras violates rules governing campaign finance (which in Colombia has been a major problem in the past). Third, paramilitary infiltration of the state corrodes public institutions. It is not only local officials who are in the pockets of the paras, and who thus become agents of impunity: the Colombian intelligence agency was recently exposed for wiretapping judges and journalists investigating the parapolitica scandal.

The problems of electoral democracy in Colombia and Venezuela are masked to some extent by the popularity of their leaders. Flawed electoral processes are less likely to provoke a political response when outcomes more or less clearly reflect a strong preference for the incumbent leadership. In this respect, it is worth noting that presidents everywhere in the Andes, except in Peru (see Tanaka and Vera), enjoy great popularity, even though satisfaction with the performance of democratic institutions is low. This is in stark contrast to the relatively recent past.

\section{CONSTITUTIONAL SEPARATION OF POWERS: A TREND TOWARD EXECUTIVE CONCENTRATION}

There is a growing concentration of executive power in Venezuela, Ecuador and Bolivia -and there is a danger that Colombia is moving in the same direction. The Venezuelan government has a super-majority in the National Assembly due to an ill-advised boycott of the 2005 legislative elections by the opposition. Some defections have reduced the initial near-unanimity of the legislature, but there is little separation of purpose between legislature and executive. Rather, the legislature has facilitated executive control over the National Election Council, the Comptroller General, and the office of the Public 
Prosecutor. The executive exercises a permanent veto on the actions of these offices because their incumbents can be removed at will by a pliant legislature. The initiative in the most important areas of legislation (including major constitutional reform proposals) has come from the executive, with the legislature acting like a virtual rubber stamp (as, for example, when the National Assembly approved the legislation setting in motion the constitutional reforms of 2007). The legislature is not a productive body; it does little more than approve conventions with other countries and other relatively superficial activities. The weakness of the legislature is due, in part, to the collapse of the party system and the lack of strong opposition parties.

Venezuelan hyper-presidentialism, to use Penfold's term, is exacerbated by the elimination of term limits following a referendum in 2009. In the absence of the rule of law and term limits, the president becomes almost unbeatable. The government has repeatedly attempted to change the constitution, and has done so by plebiscitary but not illegal means (again, facilitated by executive control over the legislature and judiciary). Constitutional reforms have tended to reinforce centralized presidential power, weaken federalism, and marginalize the opposition. Enabling laws have granted the executive the authority to legislate during three separate 18 -month periods. This means that the executive has had legislative authority for a total of $3 \frac{1}{2}$ years, or $1 / 3^{\text {rd }}$ of the entire time Chávez has been in office. The executive has made extensive use of this authority to legislate in a wide range of policy areas. Most recently 26 laws were promulgated at the end of one such period. Some of the legislation passed by this means has increased the concentration of presidential power (for example, by giving the state sweeping powers of expropriation). There has been no need to bully or marginalize the legislature, due to an overwhelming government majority.

It is often suggested that Bolivia under Morales is following the Venezuelan "Bolivarian" model. The comparison is inexact. In the first place, checks and balances have tended to reflect the partisan composition of congress (that is, whether parties sought to hold the executive to account). With the election in 2005, for the first time in the current democratic era, Bolivia had a majority government (in the lower house, but not Senate). This created opportunities for the centralization of presidential power, but congress remained an important institution in Bolivian politics. Indeed, the congress was the site of negotiations that resulted in the 20 October 2008 pact that ultimately made possible the adoption of the new constitution. In the process, significant improvements were made to the text of the new constitution. There are disturbing examples of executive attempts to bully or manipulate the congress. On occasion, organizations linked to the MAS have surrounded congress and refused entry to the opposition during voting. Members of the opposition have been called away to meetings with government officials only to find that the congress was voting on legislation while they were away. Nevertheless, congress remains considerably more than a rubber stamp for the executive.

The erosion of the independence of the judiciary by the MAS government is a more disturbing trend. The public ministry has been co-opted; salaries have been drastically cut (as much as 60 percent); tribunals have collapsed as a result of resignations of judges. (Three magistrates resigned from the TC, and four from the Supreme Court). There is 
little impetus to reform from within. In many parts of the country there is no access to justice whatsoever. Criminal accusations have been used as a way of pressuring adversaries. Consider the way that Morales unconstitutionally terminated the tenure of the Constitutional Tribunal. A $2 / 3^{\text {rds }}$ majority in congress (total, not just those present) is needed to appoint members of the Constitutional Tribunal, Supreme Court, and Election Court. The legislators of the MAS did not have such a majority but insisted that there was a precedent for making interim appointments with a simple majority. President Morales attempted to name 4 judges to the TC by simple majority, and was rebuffed by congress. When the TC upheld the 2/3rds rule the majority of judges were sued for prevarication by the President, leaving the TC inoperative. Following his re-election in December 2009, Morales, using special powers granted him by the legislature, appointed 18 top judges, including supreme court justices. The move raised fears that the new government was seeking to stack the judiciary. The politicization and emasculation of the judiciary become all the more important in light of evidence of corruption in the MAS.

In Ecuador, the concentration of executive power is more in line with the Venezuelan model, in that it involves both the subordination of congress and the courts, and it is all the more surprising given the country's recent history. As Santiago Basabe and his coauthors note, since 1996 no Ecuadorian president has served his full term in office; each has been removed extra-legally. In every case, the legislature played a key role. The removal of presidents before the end of their terms constituted unconstitutional encroachments on executive power. Indeed, conflict between legislature and executive has been a pervasive feature of democratic politics in Ecuador. The most dramatic recent example was the conflict between President Correa and the congress over the decision by the Supreme Electoral Tribunal, to call for a "popular consultation" to convene a constituent assembly. When the congress rejected this decision, removed the head of the TSE, and ordered the trial of the members of the TSE who supported the decision, the TSE replied by removing the 57 deputies who had attempted to sack them. With the majority of members of congress in the hands of alternates, the government was able to get its way. The TC tried to support the suspended legislators, but the new congressional majority removed the judges of the TC on grounds considered arbitrary and unconstitutional.

Conflicts between legislature and executive have politicized the judiciary, and judges have become political agents. The new constitution creates a supreme court that is weaker and less autonomous, and a very powerful constitutional court, with few mechanisms of accountability. The new Constitutional Court is a key element in the new political system. It can override the supreme court. Its concurrence is necessary for the president to dissolve the legislature, or for the legislature to impeach the president. Its support must also be secured before any legislative initiative of citizens, or any popular consultation. Yet the Constitutional Court cannot be held accountable - there is no political justice for its members. The new constitution also creates a more powerful executive, one with extensive executive prerogatives and legislative powers. The president can initiate legislation in urgent economic matters, veto legislation, and propose alternative laws that can only be defeated by a super-majority. Agents of horizontal accountability are placed outside the control of the legislature, reinforcing the executive. 
The similarities and differences between Colombia and the other Andean nations are instructive. President Uribe has sought to concentrate executive power, but he is operating in an institutional environment with a more robust constitutional separation of powers. Uribe is an outsider. He ran as an independent in both the 2002 and 2006 elections, and has governed with a heterogeneous and fragile coalition, but one that has nonetheless afforded his government a legislative majority. The biggest threat to his majority is the fact that 73 members of congress are under investigation as a consequence of the parapolitica scandal, and 30 have been sentenced and imprisoned (see Botero, Hoskin and Pachón). Many of those implicated in the scandal are from the government coalition. Some lawmakers have resigned their seats rather than be investigated by the constitutional court. They believe they have a better chance if they are tried in common courts (moreover, they always have the possibility of appeal).

A political reform to address the parapolitica scandal sank when it became clear that any sanctions imposed on parties for involvement with paramilitaries would result in the loss of the government's majority. The executive has strong legislative and other powers, including: procedural and substantive veto; broad powers to declare a state of siege; the ability to prioritize a bill through an urgency petition; and areas of exclusive rights to legislate (regarding ministries, public sector salaries, budget, trade, tariffs, debt). The executive also has extensive powers of appointment and nomination. The 1991 Constitution imposed a strict "no-re-election" term limit, which was changed in 2005 to enable Uribe to be re-elected, without other measures being taken to ensure the balance among branches of government from being altered. Critics of re-election suggested that the longer presidential term created the threat that the executive would be able to exert his administrative and appointment powers to pack the courts, control other agencies of horizontal accountability, and influence the central bank. Had Uribe been allowed to run for a third term, this would have further increase presidential powers. However, in a landmark decision in February 2010, Colombia@^s constitutional court voted 7-2 against a referendum to allow Uribe to run for a third term, largely on the grounds that another term would weaken checks and balances in Colombia@^s democracy.

The biggest difference between Colombia and most of its Andean neighbors is that it has a remarkably independent and energetic judiciary. Uribe has tried to rein it in, and he has also tried to turn public opinion against the judiciary, but so far has failed. Had he been allowed to run for re-election, he would have been able to continue to extend his influence over the court system. The Constitution of 1991 strengthened the powers of the judiciary, and created new judicial bodies (including a constitutional court), reorganized its functions and competencies, and created new instruments to protect fundamental rights and freedoms. It provided the judiciary with a legal figure known as "acciones de tutela," (injunctions) which are sweeping powers to protect rights. Injunctions are initiated by citizens to demand justice from the courts. Judges can issue injunctions against other citizens (including government officials) in defense of rights on penalty of incarceration. As a result, the courts have an important role in setting the legislative agenda, as congress must provide appropriations to ensure compliance with injunctions. Citizens can take their injunctions to congress and demand their rights be upheld. As a 
result, citizens increasingly turn to the courts before lobbying parties (this is also because parties have tended not to be as effective in protecting rights).

The executive has challenged the powers of the judiciary, especially by seeking to debilitate the constitutional court as a final interpreter of the constitution (on the grounds that this makes it a legislator). The executive seeks to reduce the acciones de tutela, and weaken judicial control over exceptional measures. At the administrative level, the executive has acquired greater influence over the supreme court. For example, he has appointed all the magistrates in its disciplinary chamber. Uribe has had frequent altercations with the supreme court, especially regarding investigations into the parapolitica scandal. The executive has repeatedly submitted counter-reform measures to weaken the sweeping powers of the judiciary that were written into the 1991 Constitution in a deliberate effort to check executive power. Another disturbing feature of Colombian democracy is the tendency to respond to protests with repression or to criminalize dissent, a pattern observed in virtually all the other Andean cases to some degree as well.

\section{FROM CRISIS OF REPRESENTATION TO PARTICIPATION REVOLUTION}

In an attempt to address the growing concern with inclusive citizenship that has animated many of the most important democratic innovations in the region in recent years, the methodological template encouraged researchers to assess civil, political, and social, economic and cultural rights. In the course of our research we recognized the importance of focusing on models of participation, in addition to rights of citizenship, and we amended our Decalogue accordingly.

In the contemporary Andean context we witness the proliferation of new mechanisms of more direct participation. Rafael Roncagliolo and his collaborators have documented a wide range of forms that direct democracy can take which include, inter alia, referenda (citizen or government initiated), recall, citizen legislative initiatives, community councils, and participatory budgeting. ${ }^{7}$ Participation in constitutional reform is another important mechanism of direct democracy. A key question that we must ask, at least from the point of view of the assessment of the state of democracy, is whether these new mechanisms of participation will reinforce or weaken representation. All too often, participation is framed as a replacement for representation, but the evidence, at least in terms of direct democracy and participatory budgeting; shows that participation works well where representation also works well (Selee and Peruzzotti 2009); even though it may be used to undermine the quality of democracy where representation is in crisis.

In Venezuela, there has been an explosion of participation, from Bolivarian circles, to units for electoral battles, to units for endogenous development, and now Communal

7 See Rafael Roncagliolo et al., "Ejercicio de la representación y la participación política: el caso de Perú," unpublished report prepared for the Andean Democracy Research Network. 
Councils. ${ }^{8}$ These organizations are chartered and regulated by the state, and there are mechanisms of vertical control that reduce their ability to serve as mechanisms of social accountability. Thus, for example, Communal Councils (which are estimated to number in the thousands) are designed to be the backbone of popular, "protagonistic," participatory democracy. They are typically structured around five elements: an assembly, an elected executive, a credit cooperative, a social control unit, and working groups. They are created by means of a constituent assembly (Article 19, Communal Councils Law), and have access to public funding. The Councils have a pluralistic membership (in one survey, 8 out of 10 Councils have members with different political viewpoints [Machado 2008]), which reflects the high level of democratic conviviality at the local level. Communal Councils may serve as "schools" for participatory democracy, and provide basic services like places where family violence can be reported.

At the same time, the Communal Councils fall under the jurisdiction of a Presidential Commission - in other words they are fiscally controlled by the President. It is clear, as Penfold argues, that the Community Councils are designed to allow the executive to penetrate areas of local and gubernatorial jurisdiction. Their decision-making is restricted to micro-level issues of concern to local communities, issues of housing or infrastructure; they are in no way a counter-weight to executive power, no impact at the national level. It is as yet unclear how resources will be managed through this system.

Bolivia is another country that has experienced a substantial increase in direct participation. With the collapse of the party system, the emergent model of participation is based on social movements and the governing MAS is the instrument of these movements. The MAS has contributed to the enfranchisement of rural, indigenous, and other historically excluded groups, and it is active throughout the national territory. The MAS has also encouraged the participation of women, and women were an organized part of the MAS from the start. Women hold 30 percent of the positions within the MAS (they are, however, less well represented at the cabinet level). In addition, the new constitution recognizes the multiethnic and pluricultural character of Bolivia. Bolivia ratified ILO Convention 169, recognizing the right to land and self-determination of indigenous peoples. The Law of Popular Participation recognizes urban and rural communities (juntas vecinales, comunidades indigenas) as agents of participation at the municipal level. The Law of Agrarian Reform grants the right of collective ownership of land. The Law of Environment gives indigenous communities management of biodiversity, while the forest law places agrarian rights above the right to log, and the hydrocarbon law gives indigenous control over oil and gas in their territories. 12,000 communities have been granted legal personality, and indigenous people are granted representation in all legislatures and the executive. Thousands of indigenous communities have benefited, as well as communal peasant and smallholdings. ${ }^{9}$ 
Ecuador's new constitution adopted participatory mechanisms including legislative initiative, popular consultations, and recall. These are not all entirely new. There have been popular consultations since 1967, and legislative initiative and recall have been enshrined in law (but never used) since 1978. The new constitution creates an "empty seat" in local governments to be occupied by civil society stakeholders. It encourages participatory budgeting and open assemblies (cabildos abiertos). In the new constitution, mechanisms of direct participation are given a more central place: it is easier for citizens to initiate legislation, and it is easier to initiate referenda, but the initiative must be accepted by the constitutional court.

Since 1980, Peru has progressively adopted more mechanisms of direct participation. The first step was decentralization (begun in 1988 but interrupted in 1992)..$^{10}$ The 1993 Constitution enshrined mechanisms of direct participation such as referenda. Under President Paniagua, decentralization was resumed, and participatory budgeting was passed into law. Today Peru and Venezuela are the two countries that have the juridical frameworks most favorable to participation, though in practice Peru has lagged behind Venezuela in promoting participation. The main legal instruments that Peru now has include Referenda Law 26300, enacted in 1993, entitled Right of Participation and Citizen Control. This allows for popular consultations and citizen initiatives. Both president and citizens can call for referenda to change the constitution or laws. Law 26300 allows citizen-initiated legislation, provided such initiatives have the support of at least 0.3 percent of the electorate. Voters in any district can remove their elected officials by a recall referendum. To call a recall vote, 25 percent of the electorate must sign their support for the initiative. Participation has been encouraged through changes in legislation governing decentralization, municipalities, and participatory budgeting (which occurs in as many as 1,800 districts of Peru). A forum for dialogue has been created with the purpose of bringing together government and civil society around a common agenda for development.

Chile is often extolled as an exemplary democracy, yet when it comes to participation it has lagged. ${ }^{11}$ There is no recall, no citizen initiative, no communal councils, no local assemblies, and very little participatory budgeting. The absence of participatory mechanisms in Chile might be explained by its authoritarian constitution, or the gap between parties and civil society, but it also reflects that lack of interest in promoting direct participation by the government in the context of a political system with stable parties and a well-institutionalized bureaucracy. The spread of participation elsewhere in the Andean region has occurred largely because governments have come to office that wish to encourage participation, and the form that mechanisms of participation have taken reflects governmental objectives as well as demands from civil society. It is, therefore, necessary to inquire into the reasons for the adoption of participatory mechanisms, especially in light of the aforementioned crisis of representation. 
In some cases, participatory mechanisms appear to have been designed to exploit the weakness of representative institutions -parties and legislatures- and enhance executive power. President Chávez appears to see the potential for rivals to emerge from the regions, so he has put roadblocks in the way of ambitious governors and mayors. Part of the motivation behind the creation and funding of Communal Councils is to weaken local and regional governments. By creating non-elected parallel powers, bypassing representative institutions, the power of the central government is reinforced at the local level. The central government has obstructed the inauguration of elected governors and mayors, cut their budgets, and limited their powers. The elected mayor of Caracas, Antonio Ledezma, had his budget cut by 80 percent by the central government, and an un-elected vice-president was appointed for Caracas, assuming some of the mayor's functions. The central government ignored the National Association of Governors and created the Association of Bolivarian Governors. In short, the spread of Community Councils is part of an attempt to create direct linkages between the executive and the grassroots to short circuit existing structures of representation.

Despite their differences, there are parallels between the way in which President Uribe in Colombia and Chávez in Venezuela have used mechanisms of direct consultation to reinforce executive power and bypass parties and congress. President Uribe has held hundreds of Communal Council meetings in the period between 2002 and 2007. The purpose is to promote the national development plan. Topics include security, employment, social services, urban problems, education, natural disaster management. Targets are set, and government agencies held accountable to show results. These councils have involved and benefited as many as 4 million Colombians, with 80 percent of social spending going through the president's office.

\section{CONSTITUENT ASSEMBLIES IN VENEZUELA, ECUADOR, BOLIVIA}

Every country in the Andes (excepting Chile) has changed its constitution within the past generation. Peru and Colombia changed their constitutions in the 1990s. In Peru the change occurred in a semi-authoritarian context and resulted in the expansion of executive powers. In Colombia, the constitution was changed by legal and democratic means, so that it reinforced the separation of powers. In the last decade three countries (Venezuela, Bolivia, and Ecuador) have adopted new constitutions. The process of constitutional change has not involved the rupture of the constitutional and democratic order (as in Peru in 1992). But unlike Colombia (which adopted a new constitution in 1991), the recent wave of constituent assemblies have, to varying degrees, appealed to notions of constituent power in ways that challenge liberal and representative democracy.

Constitutional reform that appeals to the inherent right of the people to change their form of government runs the risks that have always been associated with democracy. Since the time of the ancient Greeks it has been understood that democracy, unconstrained by conventions or established institutions, may create unchecked and unlimited power. Such power may provide cover for the aggrandizement of the executive branch of government 
masquerading as the embodiment of popular sovereignty. It is therefore imperative to assess whether the constituent process is truly deliberative, plural, and legitimate in terms of basic legal and constitutional principles. A brief comparison of the constituent assemblies in Venezuela, Ecuador and Bolivia exposes major differences that may well, in turn, influence the legitimacy of the emerging constitutional order. Whereas the opposition has played little or no role in the construction of a new constitutional order in Venezuela, it played a significant role in Bolivia. Ecuador represents an intermediate case.

Chávez's allies overwhelmingly controlled the Venezuelan Constituent Assembly of 1999. The sitting congress was closed, its powers usurped. Although the new constitution was radically different from the 1961 Constitution, the process of constitutional change was used to concentrate executive power and to bring the judiciary and other government agencies under the control of the executive. Although the constitution was initially rejected by much of the opposition, factions of which attempted to remove Chávez by non-constitutional means in April 2002, it has been tacitly accepted by all parties since then. It is far from clear whether this is due to conviction or convenience, however, nor is it clear whether the Bolivarian Constitution would survive Chávez's departure from office. This uncertainty motivated the push for indefinite presidential re-election. The idea of constituent power has taken on a life of its own in Venezuela. For the Chavez government, the doctrine of constituent power implies a process that has been expanded, extended, and remains ongoing. Indeed, it has been extended to the micro-level through Communal Councils (discussed above). A second constitutional reform by referendum was attempted (unsuccessfully) in 2007; this was followed by a referendum on term limits in 2009 that passed. As Penfold notes, the elimination of term limits substantially increases executive power.

Bolivia's constituent assembly was elected to change the constitution, but significantly the government did not have the $2 / 3$ rds majority to pass a constitution made to measure. The electoral system used to select the Constituent Assembly virtually guaranteed that the government would not have the necessary super-majority to change the constitution unilaterally. There were 5 members for each of 9 department (45 in total), and then three representatives in 70 districts (total of 210). The top vote winner would take the first seat, and the runner-up would get the second. The third seat would go to the first party if it had over $50 \%$ of the vote. This made it almost mathematically impossible for any party to win 2/3rds of the seats. Yet the "Ley Especial de Convocatoria" expressly required a $2 / 3^{\text {rds }}$ majority.

The constituent assembly did not usurp the powers of congress. Within the constituent assembly, there were important flaws in the deliberative process. Much time was spent arguing over procedural rules not substance. When agreement could not be reached with the opposition, the text was approved by pro-government members only (under military protection). Nevertheless, the presence of a sitting congress, under immense pressure from Bolivia's social movements, helped resolve the impasse. The text was submitted to congress, which modified many of its articles, thereby ensuring input 
from opposition, before it was submitted to a referendum. With the 2009 referendum, the text became law.

In Ecuador, a constituent assembly rewrote the constitution and submitted it to a referendum. The constituent assembly was composed of 24 national representatives, 100 from the provinces, 6 representing migrants. The election process was conducted without irregularities. The assembly was convened under the auspices of the government, and a majority, 80 of 130 seats, was held by the governing PAIS coalition. In contrast to previous constituent processes in Ecuador, this one was more inclusive and participatory. A Social Participation Office was created which channeled input from society into the assembly, ensured these ideas were given a hearing, facilitated observation by civil society, and brought the outcome back to the public. Public hearings were held throughout the country, allowing a space for participation by citizens. As many as 70,000 people participated, and made a total of with 1,632 recommendations. Independent civil society organizations recognized the opportunities for dialogue. Citizens were then able to vote on the constitution in a popular consultation. ${ }^{12}$

Ecuador's new constitution places a strong emphasis on a broad array of rights, especially those pertaining to participation. It creates a new body with civil society representation, the Consejo de Participación Ciudadana y Control Social (or Council of Citizen Participation and Social Control, CPCCS), that through its commissions, participates in the appointment of the Attorney General, Comptroller General, Human Rights Ombudsman, National Election Council, superintendents, the Board of the Judicature. There were appointments previously made by the legislature. The selection of the CPCCS is competitive and based on merit and an exam. The composition of the CPCCS is critical because if its members side with the president, this will enhance executive power in areas that in the past were the jurisdiction of the legislature. Both critics and supporters of this new body agree that the idea is to remove political parties from the designation of these authorities (see Basabe et al.).

\section{CONCLUSIONS}

It might be tempting to rank Andean democracies, contributing to the proliferation of such indicators. In fact, our methodological template was designed explicitly to be congruent with at least one such indicator: the electoral democracy index of the UNDP. However, because we examine three separate dimensions of democracy -electoral, constitutional, and citizenship- the construction of a single ordinal (much less cardinal) ranking could be misleading rather than illuminating. It is fair to say that the cases of Colombia and Venezuela are of the greatest concern because the problems in these cases affect elections, the core institutions of democracy, and yet the problems in each case are fundamentally different. 
In Venezuela, the violation of a basic political right, the right to run for office, has occurred in a context in which the politicization of electoral and judicial institutions has limited the possibilities for redress. In Colombia, the problem lies not with electoral institutions or the judiciary, but with the penetration of the political system by paramilitary actors, and this occurs in the context of widespread abuses of human rights by both state and non-state actors. If we shift our focus to constitutional order, we observe a range of variation from Chile, where the constitutional order is extremely stable but with important authoritarian features inherited from military rule and virtually no institutional innovation to promote participation, to Venezuela where radical change has occurred, involving broader participation, in the context of increasing centralization of executive power. It adds little to say that the other cases lie between these extremes, since they do so in very different ways. Thus, there are remarkable similarities between the presidential style of Chávez and Uribe, and yet Uribe operates in a context of greater constitutional constraints. There are notable similarities in the ways that leaders in Venezuela, Ecuador and Bolivia have responded to failures of representation by promoting more participation, and yet both the process and outcome of constitutional reforms have also diverged.

One implication of our studies is that it is overly-simplistic to suggest that there are two clusters of democracy in the Andes: the precarious democracies where radical populists have come to power and are acting at the margins of the constitutional order, such as Venezuela, Bolivia and Ecuador, and the more robust and stable democracies in which responsible governments are pursuing market-friendly policies within the framework of constitutional institutions (Chile, Colombia, and Peru). ${ }^{13}$ Taken as a set, the studies here provide the foundations for a much more nuanced (if difficult to quantify) characterization. Chile's democracy shows real strengths in terms of constitutional order and the rule of law, but it is sorely deficient in terms of participation. The leaders of Venezuela and Colombia share little in terms of ideology, and they are pursuing radically different economic development strategies and international alignments, yet in important respects their autocratic leadership styles are remarkably similar. Venezuela, Bolivia, and Ecuador have all pursued constitution reform, but the deliberative quality of the processes by which reform has been sought has varied. Whereas most Andean countries are promoting grassroots participation in the response to the failure of representative institutions, Peru has neglected the mechanisms that it has available in an efficacious way - with tragic consequences in the case of the massacre at Bagua. The larger point is clear: one-dimensional understandings of democracy are potentially misleading, and that there are manifold tensions between different components of the democratic regime emerging in the Andes.

A key question for the immediate future concerns whether participation must undermine representative institutions. Are we witnessing yet another example of the tendency toward delegative rule in Latin America, the inevitable consequence of which will be to erode representative democracy and the constitutional separation of powers? Such a view has some foundation, but it is important to recognize differences in the emerging models 
of participation. For example, a major difference between Bolivia and Venezuela is the relative power of social movements in the former prior to the election of Evo Morales, on the one hand, and the greater need of the Morales government to negotiate with the opposition once in power, on the other hand. As a result, the constitutional order emerging in Bolivia, and reinforced by the re-election of Morales in December 2009, represents a synthesis between existing forms of representation and new mechanisms of direct participation. The assessment of democracy in the Andean region suggests a lesson that transcends the current conjuncture in this particular piece of geography: there is no single type of democratic regime. An ecological metaphor is useful. Democracies are complex, interdependent ecosystems, and they constantly evolve and adapt to changing conditions. ${ }^{14}$ Rather than ranking countries on scales that suggest progress from lower to higher levels, we should think of democracies as dynamic systems that must balance electoral processes, constitutional order, and participatory action.

\section{REFERENCES}

Cameron, Maxwell A. and Eric Hershberg, eds. Forthcoming. Latin America's Left Turns: Politics, Policies and Trajectories of Change. Boulder, Colorado: Lynne Rienner Publishers.

Dahl, Robert. 1971. Polyarchy: Participation and Opposition. New Haven: Yale University Press.

Machado, Jesús E. 2008. Estudio de los Consejos Comunales en Venezuela. Caracas: Fundación Centro Gumilla.

O'Donnell, Guillermo. 2007. Dissonances: Democratic Critiques of Democracy. Notre Dame: University of Notre Dame Press.

Przeworski, Adam. 1991. Democracy and the Market. Cambridge: Cambridge University Press.

Selee, Andrew and Enrique Peruzzotti. 2009. Participatory Innovation and Representative Democracy in Latin America. Baltimore: The Johns Hopkins University Press.

United Nations Development Programme, 2004. Democracy in Latin America: Toward a Citizens' Democracy. New York: United Nations Development Programme.

Maxwell A. Cameron (Ph.D., California, Berkeley, 1989) teaches comparative politics (Latin America) and international political economy at the University of British Columbia. His publications include Democracy and Authoritarianism in Peru (St. Martin's 1994), The Peruvian Labyrinth (Penn State University Press, 1997), The Political Economy of North American Free Trade (McGill-Queen's 1993), To Walk Without Fear: The Global Movement to Ban Landmines (Oxford, 1998), The Making of NAFTA: How the Deal Was Done (Cornell, 2000). In 2005 he was Canadian Bicenntenial Visiting Professor in the Yale Center for International and Area Studies. In 2006, Cameron served as political advisor to Lloyd Axworthy, Chief of the Electoral Observation Mission of the Organization of American States in Peru. Through the Centre for the Study of Democratic Institutions, he worked on the Andean Democracy Research Network to monitor and report on the state of democracy in the sub-region, with funding from the Glyn Berry Program of the Department of Foreign Affairs and International Trade, Canada. (Email: Cameron@politics.ubc.ca) 